Check for updates

1 Science Policy Research Unit (SPRU), University of Sussex

2 London School of Economics

3 Queen Mary University London

Twitter: @DrJRMoon, @clarewenham, @DrSophieHarman

Cite this as: BMJ 2021;375:n2786 http://dx.doi.org/10.1136/bmj.n2786

Published: 12 November 2021

\section{SAGO has a politics problem, and WHO is ignoring it}

Joshua Moon, ${ }^{1}$ Clare Wenham, ${ }^{2}$ Sophie Harman ${ }^{3}$

The World Health Organisation's (WHO) Scientific Advisory Group on the Origins of Novel Pathogens (SAGO) has recently been established to "define and guide studies into the origins [of Novel Pathogens]" and "advise WHO on prioritising studies and field investigations into [Novel Pathogens]." In both of these, an attention to political questions like "which pathogens deserve investigation?" and "how should countries' possible pathogen origins be prioritised?" will need to be addressed.

However, arguments have been made by WHO that SAGO should "follow the science" and "avoid politicisation." There is a clear tension here. The statement to "avoid politicisation" is a political act in itself. It is an act that suggests states, government, and citizens have no business in holding science to account. In turn it is an act that both recognises the role and importance of politics, but sees the answer as doing nothing about it. Politics is framed as a problem-a major stumbling block to both pandemic preparedness and response, and for science to do its work-but one best avoided rather than understood. Political expertise is reduced to the important work of diplomacy or political communication. There is also an assumption that all political engagement means partisan or geo-politics, which is a misnomer. Politics is located at all levels, from the micropolitics of the Wuhan laboratory to the geopolitics of the G7 and UN systems. The publication of the membership of SAGO shows a lack of attention to expertise in the social sciences, and politics in particular. ${ }^{2}$ This is sure to cause problems in two domains core to the functioning of SAGO: the politics of pathogenic origins, and the politics of global investigations.

\section{Politics is core to pathogenic origins}

The origins of novel pathogens is circumscribed by politics as much as it is by natural factors. First, human-animal interactions are driven by the political economy. A growing body of evidence shows that decreased biodiversity, changes in land use, and increased deforestation have a marked effect on the diversity of hosts and frequency of human-animal interactions with potential for pathogenic spillover. ${ }^{3}$ Importantly, these are not natural events, but changes in ecology driven by global political economic forces. ${ }^{4}$ This is furthered by understanding the local political economy of markets and the everyday engagement that individuals have with animal reservoirs, and in turn who they further expose. Without expertise in understanding these diverse drivers of land use change and local political economy, any understanding of pathogenic origins is incomplete.

Further to this, and relating more closely to the political nature of SARS-CoV-2 investigations, the nature of any "lab leak" origin (be it accidental or deliberate) is inherently political in nature. The location of BSL-4 laboratories have been subject to political choices with implications at the local level. Much maligned "gain-of-function" research performed with an intent to create new vaccines have political implications in terms of their dual-use potential. ${ }^{5}$ Even the biosafety systems put in place to prevent laboratory accidents are determined by political and social factors. Investigating novel pathogen emergence therefore also requires an understanding of the politics of biosafety and biosecurity.

Beyond this, politics determines how SARS-CoV-2 was able to spread, and who knew about its emergence when. Structures of power within laboratories, public health systems, district, provincial and national government would have determined how the disease may have spread before national, and indeed global reporting. Unpicking these governance structures requires social science expertise, beyond understanding the virology.

Pathogenic origins, then, are replete with local, national, and global political dynamics with implications core to emergence and re-emergence of the pathogen. The political drivers of pathogen emergence and re-emergence are thus a fundamental part of understanding novel pathogens. Given everything we have learned about the role of social science in pandemic governance in the last 20 months (or indeed the last 20 years), the lack of political science (or social science more generally) expertise on SAGO represents a major gap in knowledge and membership of the group.

\section{Politics is core to global investigations}

Politics is not only an object of investigation for SAGO, but it is a key facet of its organisation and activity. The origin of SARS-CoV-2 is a highly contested issue of global politics, with an increasing focus on "lab leak" hypotheses as an alternative to the traditional "spillover" hypothesis. Both the Chinese Government and the United States Government have commissioned investigations into the origins of SARS-CoV-2, while WHO itself commissioned an investigation which reported in March 2021. ${ }^{6}$ The second phase of WHO's investigation, however, has been marred by a lack of Chinese cooperation precisely because of WHO's politics; its nature as a consensus body rather than authoritative body means that it has no power to compel member states to participate in investigations, it can only persuade or incentivise. This is a common issue in international organisations and one that WHO has come up against repeatedly. ${ }^{7}$ Moreover, many states may use WHO's role and the origins narrative as a smokescreen to obfuscate their own domestic failures in mitigating covid-19, making the 
process highly political at both global and domestic levels. However, limited political expertise in navigating these political spaces on the SAGO panel risks scuppering investigations before they get off the ground.

Further to this, once an investigation has begun it is conducted under the microscope. A useful analogueue for this is investigations of alleged biological weapons use within the context of the United Nations Secretary General's Mechanism. While the specific politics are slightly different, the lessons from those investigations remain the same: conducting an investigation under the microscope requires a myriad of both technical and political competencies. ${ }^{8}$ Not least, it requires an understanding of the politics of the institutions and states under investigation, to understand the context in which results are delivered. This extends to transparency of the investigation itself through extensive sample collection and record-keeping, parallel and independent laboratory analysis of samples, and clear testing of hypotheses; but also to the communication and reporting of the investigations' results. Communicating to both a technical and a political audience is no mean feat, and requires sensitivity to the use of narrative and how reporting demonstrates the veracity of findings while also being contextually sensitive.

\section{SAGO needs a radical reframe}

The idea that SAGO could ever be "apolitical" or that it could advise only "on technical and scientific considerations" is not only naive, but ignores a key component of the work to be done in origins investigations. Fixing this requires, first and foremost, that the membership of the group include political and social scientific expertise; this is a minimum requirement. Once included, this expertise must not be side-lined, or viewed as secondary to the science. Going deeper, however, it needs to be acknowledged that SAGO is stepping into a space that is already politicised, and that inherently requires a sensitivity to politics. This has already been acknowledged by WHO itself, who reopened its call for membership "to encourage additional applications from the fields of social science/anthropology/ethics/political science and biosafety/biosecurity." 9 However, this was followed by the announcement of two more scientists to the panel, not social scientists, running contrary to the call for social science expertise. ${ }^{10}$ This flies in the face of the additional call and demonstrates something far worse of WHO's intentions for SAGO. SAGO needs to see the political landscape, how it shapes it, and how it can navigate it, to not walk blindly into a minefield of its own making; but WHO's call for social science expertise, only to appoint more scientists, shows at best wilful ignorance of politics and political expertise or, at worst, active contempt.

Competing interests: None declared.

Provenance and peer review: Not commissioned, not peer reviewed

Stern G. Twitter. https://twitter.com/gabbystern/status/1450719132161388545?s=21

2 WHO. Public notice of proposed new Scientific Advisory Group for the Origins of Novel Pathogens (SAGO) members. https://www.who.int/news-room/articles-detail/public-notice-and-commenton-proposed-new-scientific-advisory-group-for-the-origins-of-novel-pathogens-(sago)-members

3 Gibb R, Redding DW, Chin KQ, etal. Zoonotic host diversity increases in human-dominated ecosystems. Nature 2020;584:398-402. doi: 10.1038/s41586-020-2562-8. pmid: 32759999

4 Vupenyu D, Salome B, Melissa L, Lindiwe M, lan S, Annie W. Structural drivers of vulnerability to zoonotic disease in AfricaPhil. Trans. R. Soc. 2017;B3722016016920160169. doi: 10.1098/rstb.2016.0169.

5 Gillum D, Moritz R. 2021. Why gain of function research matters. The Conversation. https://theconversation.com/why-gain-of-function-research-matters-162493

6 WHO-convened global study of origins of SARS-CoV-2: China Part. 2021. https://www.who.int/publications/i/item/who-convened-global-study-of-origins-of-sars-cov-2china-part
7 Vaubel R. Principal-agent problems in international organizations. Rev Int Orgs 2006;1:125-38. doi: 10.1007/s11558-006-8340-z.

8 McLeish C, Moon JR. Sitting on the boundary: the role of reports in investigations into alleged biological-weapons use. Nonprofil Rev 2021. doi: 10.1080/10736700.2020.1872968.

9 Re-opening - additional call for experts to join the Scientific Advisory Group for the Origins of Novel Pathogens (SAGO) https://www.who.int/news-room/articles-detail/re-opening-additionalcall-for-experts-to-join-the-scientific-advisory-group-for-the-origins-of-novel-pathogens-(sago)

10 Public notice of proposed new Scientific Advisory Group for the Origins of Novel Pathogens (SAGO) members https://www.who.int/news-room/articles-detail/public-notice-and-commenton-proposed-new-scientific-advisory-group-for-the-origins-of-novel-pathogens-(sago)-members 